\title{
Developing Mathematics Teaching Devices in the Topic of Trigonometry Based on Guided Discovery Teaching Method
}

\author{
Naufal Ishartono ${ }^{(1}$, Dwi Juniati ${ }^{(2}$, Agung Lukito ${ }^{(3}$ \\ 1) Universitas Muhammadiyah Surakarta \\ 2) 3) Universeitas Negeri Surabaya \\ Corresponding author:naufal.ishartono@ums.ac.id
}

\begin{abstract}
This research is categorized as Research and Development ( $\mathrm{R}$ \& $\mathrm{D})$. As developed in this research is learning device that consists of lesson plan, student worksheet, and test. This research adopts ADDIE as a $\mathrm{R} \& \mathrm{D}$ model that stands for Analysis, Design, Development, Implementation, and Evaluation. The aim of this study are to describe the development process and to produce trigonometry learning device based on guided discovery method for students of grade XI Natural Science, as well as determine the effectiveness of trigonometry learning process using Guided Discovery method. To produce the trigonometry learning device based on guided discovery method for students of grade XI Natural Science, so it requires a validation from the experts and a trial to determine its practicability and effectiveness. According to the result of data analysis, it can be concluded: (1) trigonometry learning device based on guided discovery method for students of grade XI Natural Science fulfills criterion of valid, effective and practically, and (2) trigonometry learning process based on guided discovery method is effective.
\end{abstract}

Keywords: Guided Discovery, Trigonometry

\section{Introduction}

Trigonometry is a branch of mathematics that concerns on the elements of triangle such as sinus, cosine, tangent, secant, cosecant, cotangent, and its applications (Susanto, 2008:1). Many concepts are developed from these branch of mathematics to enable people in solving their daily-life problems, namely in a construction, in music, in economy, and etc. Therefore, we believe that trigonometry need to be understood as early as possible by the people, especially in high school level. In Indonesia, based on curriculum of 2013, topic of trigonometry is formally taught in senior high school level. At grade X Science Program, the students learn the topic of ratios, functions, equations, and identities of trigonometry. While for topics of trigonometry derivative formulas and its uses are taught at grade XII Science Program.

Specifically in the topic of trigonometry derivative formulas and it uses, the students will learn at least 25 formulas which they have to understand these in any ways, and also the concepts and formulas that they have to remember when they learned trigonometry at grade X. Exactly, the demand to understand and to remember those number of formulas and concepts will be not easy for the pupils. So that, it emerges a 
tendency of the students will learn it by rote since this is the easiest way to put any information into their brain. This tendency appeared because some factors including the teacher factor, the student factor, and the learning resource factor.

From the teacher factor, the tendency can be caused by the way teacher explains, teaches, and delivers the material. There is a possibility the teacher uses a direct teaching method in explaining the way to find the formulas without giving any chance for the students to get involve during the learning process. From the student factor, as we mentioned before, it can be due to the cognitive burden arises in their mind when they are obliged to understand and to remember all of the concepts and the formulas, so they tend to use rote learning method to ease the way they understand the materials. While from the aspect of learning resources, a lot of mathematics books provided in bookstores merely give constructed steps without allocating any space for the students to be engaged in the process of finding the formulas. We can figure this condition out by observing the following samples of Indonesian Mathematics Electronic School Book (ESB):

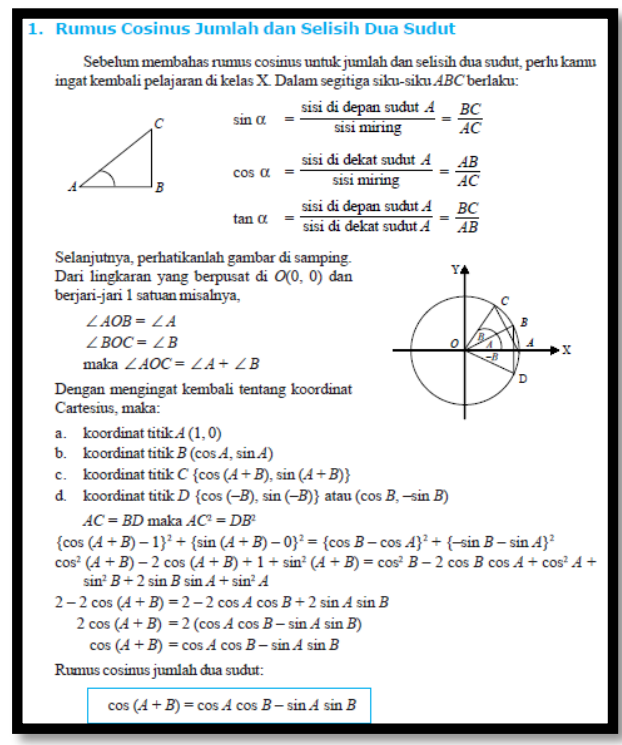

Figure 1. The sample of ESB in finding the formula of $\cos (A+B)$

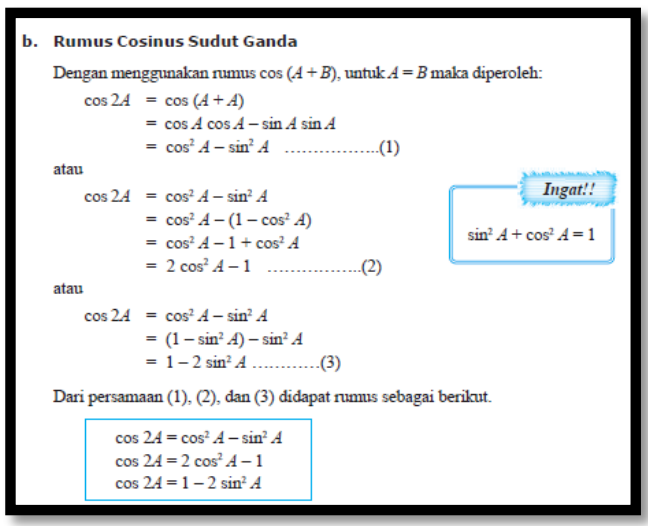

Figure 2. The sample of ESB in finding the formula of $\cos 2 \mathrm{~A}$

If we observe two figures above, it is obvious that the book does not engage the reader (in this case is the students) to find the formula since the book provides all the way to find it completed with the formulas emphasized inside the blue boxes. The first concern is, as an appropriate textbooks in general, this book does not involve student participation 
in finding the formula in question. The next concern is the emphasis given by the book that giving a possibility for the students to pay their attention not on the process of finding the formula, but also straightly on the formula. So that if the students want to memorize the formulas, this book indirectly "facilitates" them by pointing some important parts to be memorized, when in this case is the formulas. From those concerns, this can be seen that the available learning resource still less engaging the pupils actively during the learning process of finding trigonometry formulas. Therefore, the tendency of rote-learning will be inclining.

Basically, rote learning is the easiest way to take information of what we learn. However, the information learned by the students will be easily forgotten since there is nothing "memorable" left in their mind. Hence, the learning process will become meaningless. Ausubel in Bell $(1978,132)$ says, “...if the learner's intention is to memorize it verbatim, i.e., as a series of arbitrarily related word, both the learning process and the learning outcome must necessarily be rote and meaningless". By relating to Indonesian Curriculum 2013, rote-learning behavior does not support the aim of this curriculum which is the learning process of curriculum 2013 should be to get to know, not to be told. This means, in the purpose of making the class becomes less rote learning but more meaningful, the students should be actively finding out new information using their own cognitive skill and prior knowledge, not in the opposite way.

Hence, we need a teaching method to minimize the students' tendency of memorizing the material they have learned so that the learning becomes more meaningful. The method should be able to engage the pupils actively in the process of constructing trigonometric derivative formulas. Therefore, they can experience the same condition as when the formulas were invented for the first time. This experience will be memorable in the minds of the students where they understand the way the formula was constructed. So when one day they forget the formula they have learned, they will be able to reconstruct these formulas with the memory and experience they have. Therefore, one of the teaching method that is appropriate to this condition is Guided Discovery teaching method.

Historically, term of Discovery Method was given by Plato about the dialogue between Socrates and a young slave where in the next centuries this method is popularly known as Socratic Method (Cooney, Davis, \& Henderson; 1975:136). While Bruner (in Cooney, Davis, \& Henderson; 1975:136) says, "Discovery is a process, a way of approaching problems rather than a product or particular item of knowledge". Thus, Discovery teaching method is relevant to the recent Indonesian curriculum that highlighting on the process to construct a particular knowledge instead of its products. In addition, Moore (2005:259) states, "Discovery learning is an intentional learning through supervised problem solving following the scientific method of investigation". The scientific method of investigation, as what stated by Moore, has a tight relation to current Indonesia curriculum that based on scientific method, therefore this teaching method is needed and important to create a good teaching-learning quality. Furthermore, Moore says that Discovery learning can be done in three steps, depends on the solution to the problem. First, a discovery that is guided carefully (Guided Discovery). Second, a discovery that is guided accordingly (Modified Discovery). Third, a discovery that is limited only on a supervision (Open Discovery). Since our focus only on the high school students ability, so the level of Discovery learning that is chosen to be discussed is Guided Discovery.

Guided Discovery was the name to hand-on activities and laboratory investigation that led the learner to a predetermined or a predictable data set or response (Hammerman, 2006:5). While according to Bruner (2011), Guided Discovery is a teaching method based on inquiry, a constructive teaching theory within a problem solving situation where the student use their prior knowledge and experiences to find facts, correlations, and truths to 
be learned. Hence, by concluding the statements from Jerome Bruner and Moore, Guided Discovery is a teaching method that can involve the students actively to find new knowledge based on their prior knowledge under the guidance of the teacher. Through this method, the student involvement in finding the trigonometric formulas will be accommodated properly.

Of course, there is no such the best method for all learning conditions, including this method. Marzano (in Markaban, 2006:16) explains advantages and disadvantages of using this teaching meathod in class:

Table 1. Advantages and Disadvantages of Guided Discovery Method

\begin{tabular}{|c|c|}
\hline Advantages & $\begin{array}{l}\text { Disadvantages } \\
\end{array}$ \\
\hline $\begin{array}{l}\text { 1. Students will actively } \\
\text { participate during the learning } \\
\text { process. } \\
\text { 2. Instill well as foster an attitude } \\
\text { of inquiry. } \\
\text { 3. Support students' problem- } \\
\text { solving skill. } \\
\text { 4. Provide a space for interaction } \\
\text { among the students, as well as } \\
\text { students to teachers, in order } \\
\text { to train the students to } \\
\text { communicate their idea } \\
\text { properly and correctly. } \\
\text { 5. The subject being studied can } \\
\text { achieve a high level of } \\
\text { capability and longer lasting } \\
\text { because the students are } \\
\text { involve to find new } \\
\text { knowledge. }\end{array}$ & $\begin{array}{l}\text { 1. Not all of the students can follow the } \\
\text { lessons in this way since some of } \\
\text { them are still familiar and easily } \\
\text { understood by the lecturing method. } \\
\text { 2. Not all topics are suitable delivered } \\
\text { with this method. Generally, topics } \\
\text { related to the principles of the model } \\
\text { can be developed with Guided } \\
\text { Discovery. }\end{array}$ \\
\hline
\end{tabular}

Besides the advantages and the disadvantages, we also can find cognitive benefits for the students by implementing Guided Discovery teaching method in class. Here are some of them (Samuael, 2014):

1. It encourages analytic learning.

2. It exploits learners' cognitive skills.

3. It improves critical thinking skills.

4. It involves students in problem solving tasks.

5. It helps learners become aware of and articulate their mental process.

6. Learner actively in the learning process.

7. Learners understand and remember better what they have work out for themselves.

Indeed, this method has main objective in term of developing students' capability i.e. according to (Carin, 1993:A-3), "The prime objective of these (guided discovery) activities is to have students discover, and/or self-construct, the scientific/technological concept embedded in the activities as students do the activities'. In addition in the same page, Carin reminds us that although this activity has been in the design as much as possible, there will be students who do not follow the lesson plan that has been designed by the teacher. Thus, the teacher has to be flexible during the learning process.

According to Hirdjan (in Sasmito, 2012:16), Guided Discovery teaching method requires some steps as follows: 
1. Teacher determines task criteria, which is giving problem, student look for solution of the problem. The given problem should contain instructions to be made by the student, ie the students find themselves solving the problem.

2. A clever student is possible without guidance to find the answer to the problem. While students who have not been able to get answers from the problems given, get initial guidance, guidance given in the form of questions that are developed from the simplest question.

3. After the first guidance is given, students who are able to obtain answers from the problem are asked to check the correctness of the answers obtained using the data available. While for students who have not been able to get answers after being given 1st guidance, get 2nd guidance, guidance in the form of questions for the preparation of data already in the list. The purpose of the data is compiled in a list that is so that students can obtain examples of answers from some existing problems.

4. After the 2nd guidance is given, the students who succeeded in obtaining the explanation from the problem with examples of answers to the existing problem were asked to check the generosity of the answers obtained using the existing data. Students who have not been able to get an answer after the second guidance is given, get the 3rd guidance that students are given additional data on the list that has been made. The expected goal of the 3rd guidance is for answers to be found by students. If with the addition of this data students still have not found an answer, teachers need to provide additional short guidance in a way so that students immediately obtain the expected answers.

5. Students are asked to check the truth of the answers obtained after the students are given 3rd guidance or additional guidance by using existing data.

6. An answer already found to solve the problem that exists in the task criteria.

7. Students get answers from the problems assigned to the task criteria.

8. The answer of the task criteria is still guessed, so it needs to be verified (verified), so the teacher should still give confirmation that the answer obtained by the student is correct.

9. Students are given problems of application and are expected to solve these problems using the concept that just gained.

10. If the student can complete the applied problems correctly given, then it can be said that the student has succeeded in building his knowledge about a concept that is being studied and the process of learning is complete.

According to the steps above, it is obvious that the steps are very flexible which means that in the guided discovery steps there is a leap in certain steps. A concrete example in the jumps is in steps such as steps 2 and 3 , for a smart student or a student who is able to complete the first step correctly can pass 2 steps afterwards. However the steps above need some modifications to make it simple. The result of the modification is as follows:

1. Giving Problems

The teacher gives the problem, and the student looks for a solution to the problem. The given problem should contain guidance on the direction and purpose of what the student will do, ie the student finds the solution of the problem independently.

2. Data Development

In this stage, students are asked to look for other data as a continuation of known data. A clever student may be able to find out for himself the answer to the problem. While the students who have not been able to get answers from the amasalah given, get guidance, guidance given in the form of development questions starting from the simplest.

3. Data Arrangement 
Students compile data obtained from steps 1 and 2 on a data. Students who are able to get answers from the problem are asked to check the correctness of the answers obtained from the data. While those who have not been able, get guidance in the form of questions for the preparation of existing data. The purpose of the data is compiled in a list that is so that students can get examples of answers from some existing problems.

4. Data Addition

Namely the students are given guidance in the form of adding new data which will lead students to the concept or formula. Expected in this guidance, students can find the formula or concept in question. For students who have completed this activity, can directly verify it in the next stage, while for students who have not been able to complete this activity can consult with teachers or friends who have been able to solve it.

5. Verify

In this stage students are asked to verify their own formulas or concepts they have found in the Data Addition activity. If the student verification result is correct, then it can proceed to the implementation activity. While for those who have not been correct, asked to check their work results in the stages of addition of data, and can consult with teachers or friends who have successfully done the verification stage.

6. Implementation Exercises

Students are given problems of application and are expected to solve them using the concept they have just acquired.

While to create an effective teaching learning class, a good instructional devices must be generated which consist of lesson plan that includes student worksheet and test. The lesson plan would be based on curriculum 2013 and guided discovery, the student worksheet would be based on guided discovery as well, while for the test would be based on the material given in the student worksheet and the indicator in the curriculum. To develop the instructional devices, the researcher used developing model of ADDIE which consists of Analysis, Design, Develop, Implementation, and Evaluation.

Based on the description above, the researcher was interested to conduct a $R \& D$ research to develop mathematics instructional devices based on guided discovery in topic of trigonometry for student grade XI science program. The aim of this research were to develop a proper (valid, practice, and effective) mathematics instructional devices based on guided discovery in topic of trigonometry for student grade XI science program and to find out the effectiveness of the learning process using the developed instructional devices, there are two research questions about how the quality of the instructional devices is and how effective the devices implemented in the class.

\section{Research Methods}

Based on research question, this research is classified as development research, which in this process will be developed appropriate mathematics instructional devices based on guided discovery through the implementation in the trial class to get a decent tool, then implemented in another class to see the effectiveness of learning. The learning tools are lesson plan which includes student worksheet and test.

The subject in this study is one teacher and students of high school grade XI science program selected from one of the high schools in Yogyakarta. The design of mathematics instructional devices based on guided discovery in topic of trigonometry for student grade XI science program was conducted using the ADDIE development model. This model has five development steps namely Analysis, Design, Development, Implementation, and Evaluation. 
Instruments used to collect data in this study can be classified into four kinds of instruments. Each is used to meet the criteria of validity, practicality and effectiveness. The instruments are:

1. Instrument Validation Sheet by Expert

The validation sheet of the instructional device by the expert aims to determine the extent of the validity of the developed learning tool consisting of lesson plan, student worksheet, and test. In this sheet, researchers use a scale of 4 (Strongly Agree), 3 (Agree), 2 (Less Agree), and 1 (Disagree). In the validation sheet for the media expert it contains aspects of technical requirements, terms of construction, evaluation terms, and terms of implementation. For the assessment sheet by the material and learning expert contains the aspects of guided discovery, quality aspects of the content, and the aspects of didactic conditions.

2. Observation Sheet

a. Observation Sheet on Master's Ability to Manage Classroom

An observer will observe the ability of a teacher who will implement instructional devices developed into the classroom. The observer gives a check mark (V) on the appropriate rows and columns on the observation sheets of the provided learning management. The given score consists of 4 categories, that is not good (value 1), less good (value 2), good (value 3), and very good (value 4). The indicators of teachers' ability to manage learning are as follows:

1) Preliminary Phase, including the ability to inform learning objectives, motivate students, and perform apperception.

2) The presentation stage, including the ability to present the material to be studied.

3) The learning phase of the group, including the ability to organize students into study groups, guide and supervise students working in groups.

4) Enrichment stage, covering the ability of teacher to give enrichment problem in the form of quiz to measure student comprehension level.

5) The closing stage, which includes the ability to reward, confirms the essentials or essence related to learning, gives homework, and reminds the material to be studied in the lesson at the next meeting.

6) The ability to manage the time seen from the accuracy of teachers in implementing learning scenarios.

b. Student Activity Observation Sheet

This instrument is used to obtain student activity data during the learning takes place that is learning using learning device that has been developed. The student activity observation sheet contains the activities of the students in the learning process, among others: (1) listening to teacher or friend's explanation, (2) reading or understanding problems in the worksheet, (3) solving problems / finding ways and answers to problems, (4) Discuss / ask friends / teachers, (5) Draw a conclusion of a procedure or concept, (6) Treatment that is not relevant to the learning activities. 


\section{Students' Response}

According Riduwan (2009: 25-26), "questionnaire is a list of statements / questions given to others who are willing to respond (respondent) in accordance with user demand". Questionnaires to be used in this study is a questionnaire of student responses. Questionnaire student response is aimed to find out student response after learning using high school mathematics learning tools based on guided discovery on Trigonometry materials for grade XI science program students. The questionnaire is prepared with an alternative answer "SA" to Strongly Agree, "A" to Agree, "LA" for Less Agree, and "D" to Disagree. In addition, the points in the questionnaire consist of two types of points, namely points for negative statements and points for positive statements.

\section{Results And Discussion}

This research is an $\mathrm{R} \& \mathrm{D}$ research which aimed to describe the process and result of developing a proper (valid, practice, and effective) mathematics instructional devices based on guided discovery in topic of trigonometry for student grade XI science program and to find out the effectiveness of the learning process using the developed instructional devices. The descriptions are as follows:

1. The Process of Developing The Instructional Devices and Its Result

Mathematics instructional devices based on guided discovery in topic of trigonometry for student grade XI science program developed by using the ADDIE (Analysis, Design, Development, Implementation, and Evaluation) model. The developed device was in the form of lesson plan which includes student worksheet and test. The development of this tool begins with analyzing the characteristics of students, curriculum, and learning tools. The results of the analysis were used to design a draft device that would be used as a guide to develop the device. Next, the development of the device produces a prototype I which was then validated by experts. After obtained the validation results and suggestions from experts, researchers revise the device according to expert advice. Next, the device was piloted in the test class. The place to test the prototype of the device is at SMAN 9 Yogyakarta with the selection of class XI IPA 2 as a trial class.
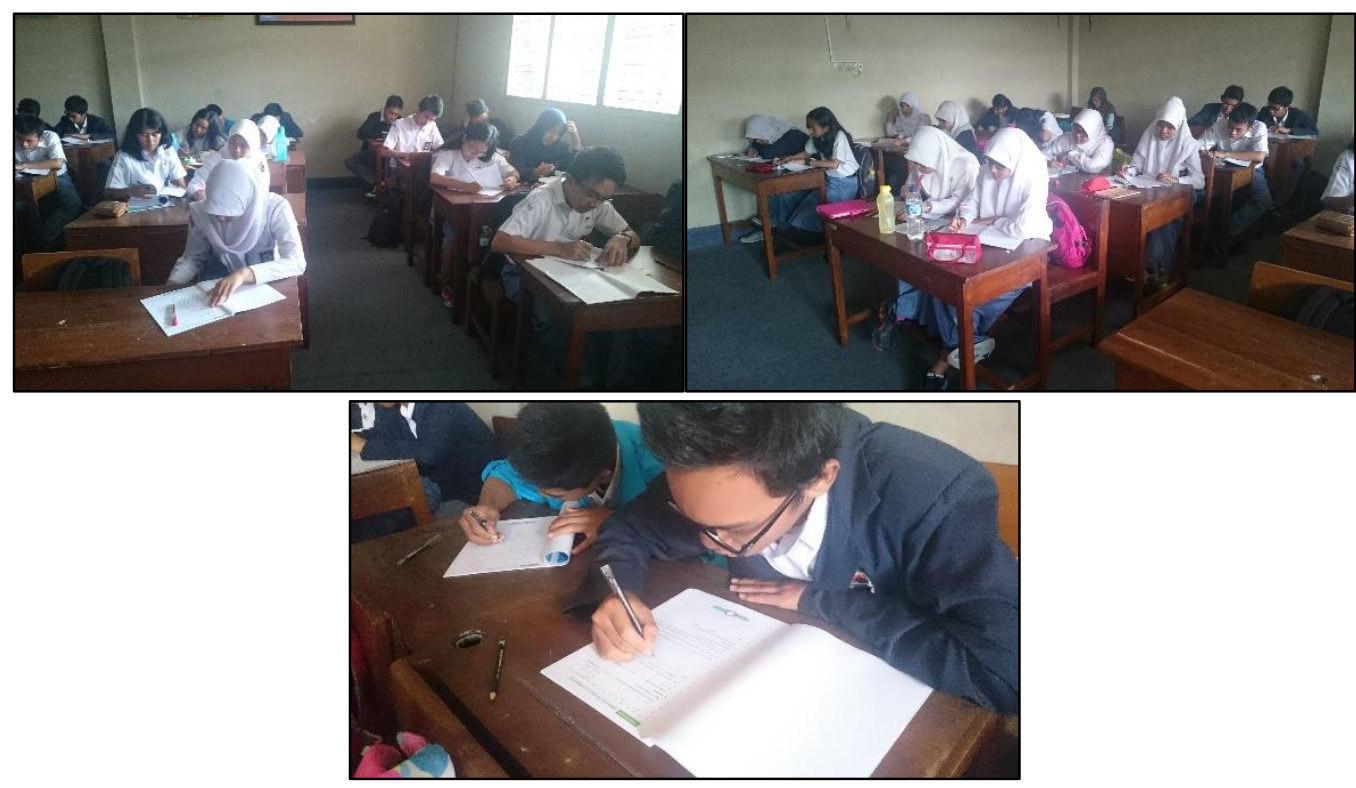

Figure 3. Students were doing the worksheet. 
Once tested, the learning device was revised in accordance with the evaluation results after the prototype trial process. Then, the learning device was implemented in the implementation class which in this case was in class XI IPA 5. In the implementation phase of trial and implementation of the device, the teacher provided lesson plan and student worksheet devices used in three meetings. Specifically on the student worksheet device, there were 3 student worksheet to be used per each meeting. In student worksheet 1, the material discussed was about the number and the difference of two angles. In the learning of trigonometry derived derivative formulas, what was presented in student worksheet 1 was about finding the formula $\sin (\mathrm{a} \pm \mathrm{b}), \cos (\mathrm{a} \pm \mathrm{b})$, and $\tan (\mathrm{a} \pm \mathrm{b})$ was the basis for finding subsequent trigonometric derivatives formulas. Therefore, the involvement of students in finding this basic formula accommodated in student worksheet 1 by using the steps in the Guided Discovery method (Giving Problem, Data Development, Data Arrangement, Data Addition, Verification, and Implementation) will assist them in constructing the formula, so students will know the process of formation of these formulas and will be more embedded in the minds of students than when they memorize it. This is in line with Bruner's opinion (in Carin and Sund 1989: 95-96) that when students find a concept independently, it will be very easy to remember and more lasting, than when students remember by reciting and pronouncing it. In other words, the involvement of students in the process of discovery of the formula will make learning much more meaningful.

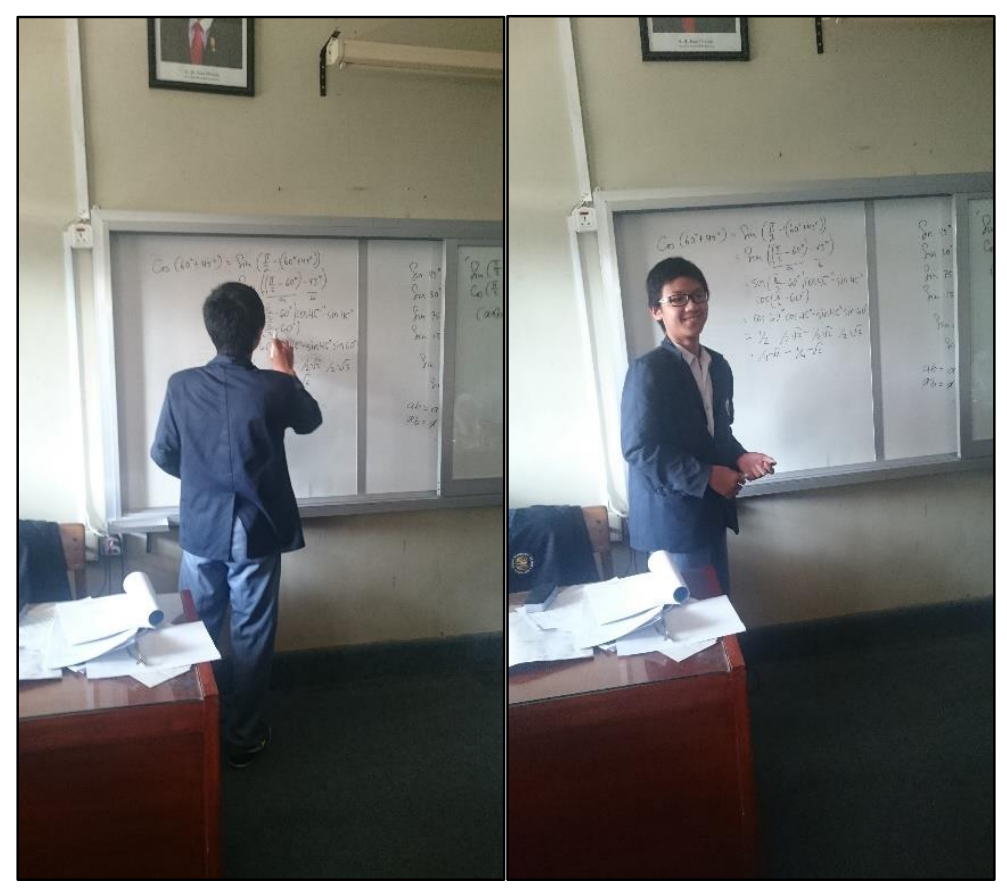

Figure 4. A student showed his discovery in front of the class.

Next on student worksheet 2, students were asked to find trigonometric derivative formulas for multiple angles using what they had found in student worksheet 1 . In this student worksheet 2 there were some steps that are eliminated, namely Data Development and Data Expansion. In student worksheet 3, students were asked to find trigonometric derivative formulas for half angles, where the preparation of the steps of the invention of the trigonometric derivative formula was based on the results of the discovery of student worksheet 2 , especially in the invention of the Cos $2 \mathrm{a}$ formula. The guided discovery steps can be seen in the following pictures and explanations: 
Table 2. The sample of guided discovery steps in the student worksheet that consists of 1) Giving Problem, 2) Data Development, 3) Data Arrangement, 4) Data Addition, 5) Verification, 6) Implementation Exercise

Steps Picture

1

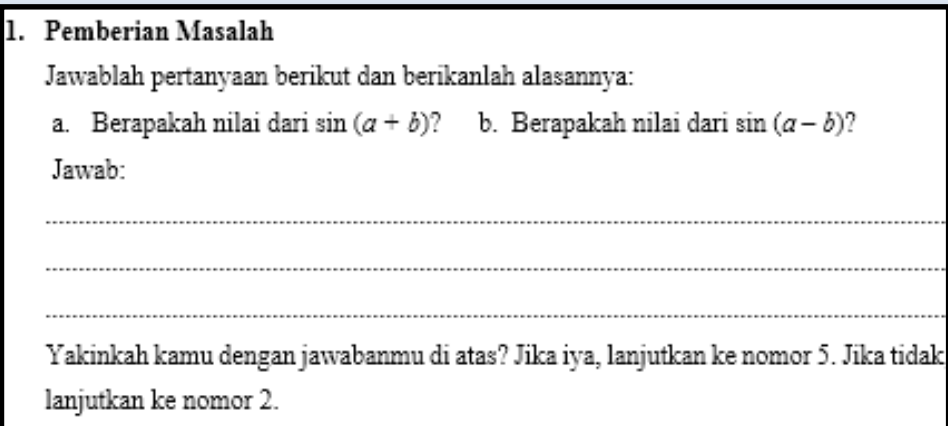

Yakinkah kamu dengan jawabanmu di atas? Jika iya, lanjutkan ke nomor 5. Jika tidak

lanjutkan ke nomor 2 .

In this stage, students are given the question of whether they can determine the value of (say) $\sin (\mathrm{a}+\mathrm{b})$ and $\sin (\mathrm{a}-\mathrm{b})$ by giving reasons or explanations. If the student is satisfied with the answer, the student may proceed to the Verification stage if they find difficulties may return to the activity after finishing the Giving Problem Stage. If they do not, students can continue to the next activity.

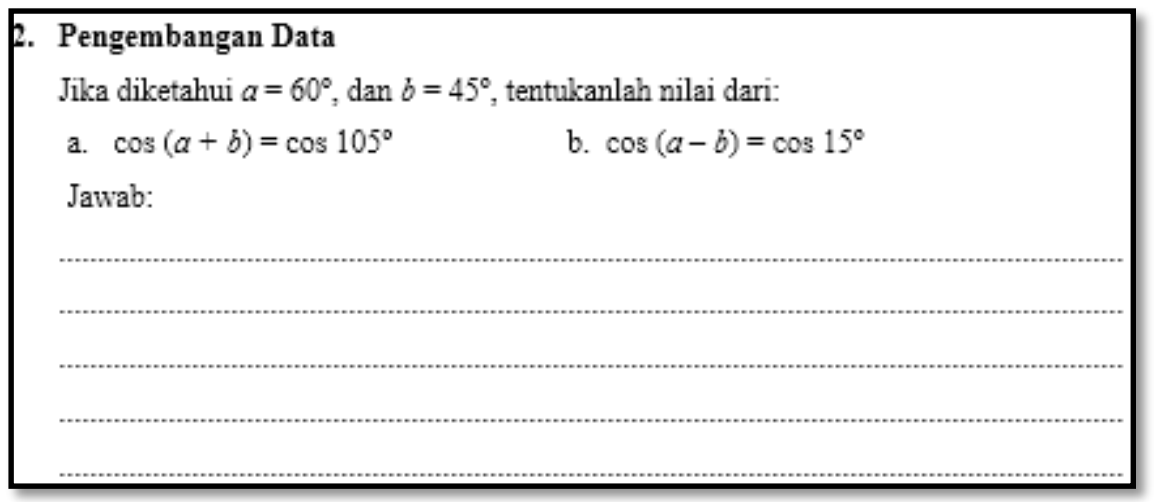

In the example in figure above, the students get guidance of new data by asserting $a$ and $b$ into numbers. If students can find answers to these activities, students are expected to find the value of the trigonometric derivative formulas in question. 
3

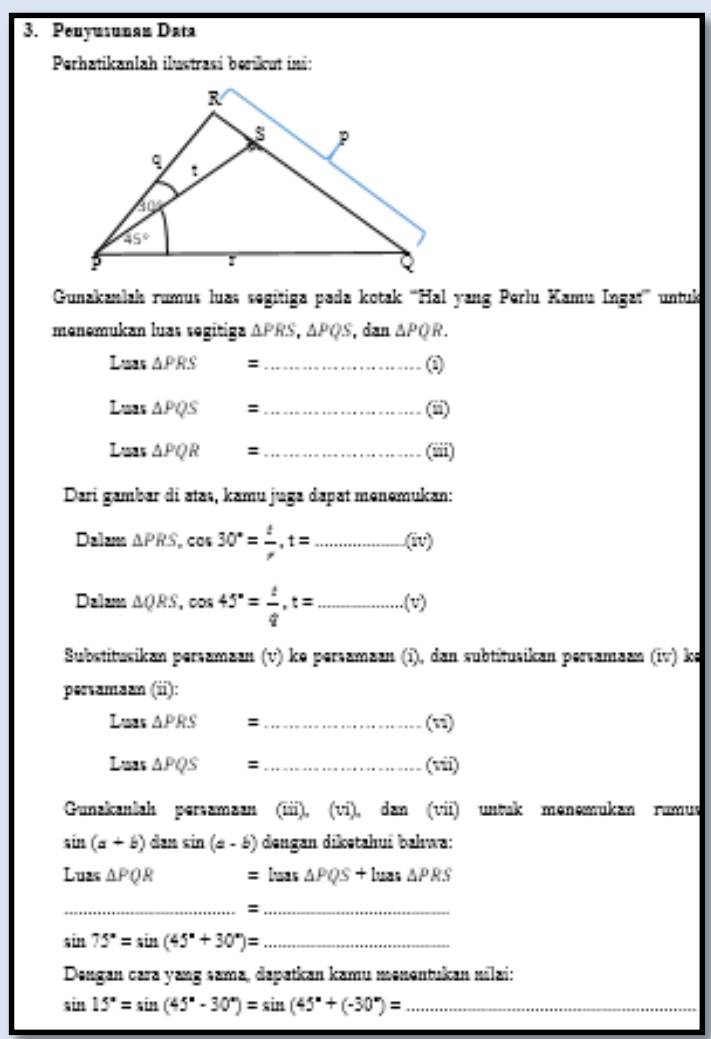

In the example above, students use the data they have on Data Development activities, and arrange them more structured to derive the trigonometric derivative formulas in question.

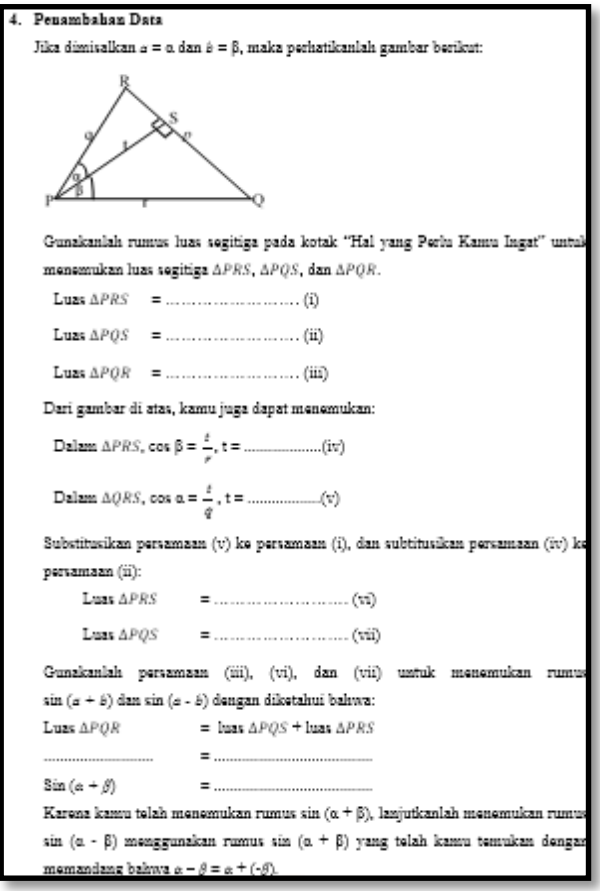


In the example above, the angle that was originally a number, was changed to a variable. In the way it works, students do the same thing with the stages of Data Arrangement.

5

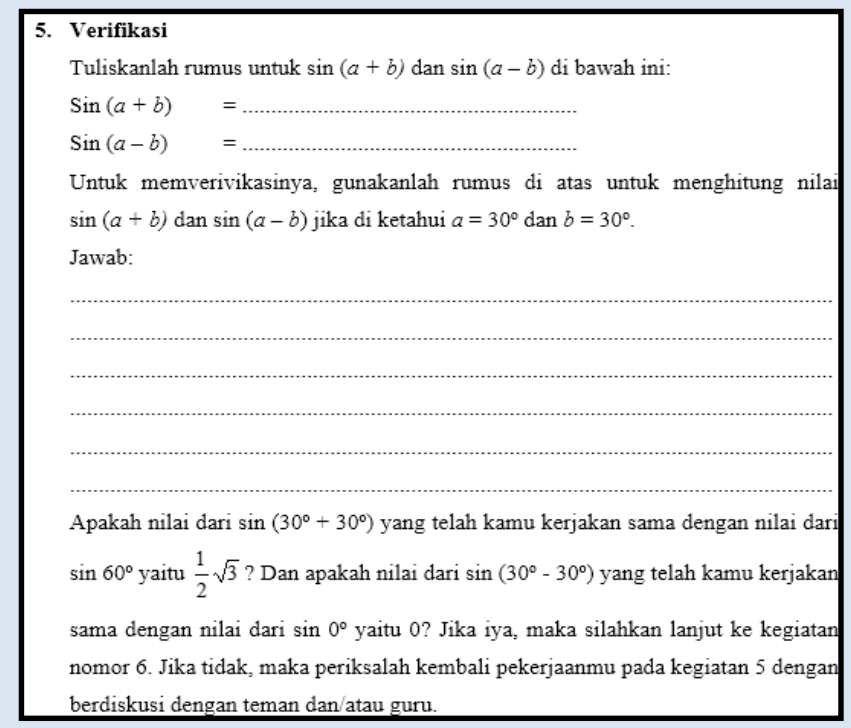

In the above example, students are asked to rewrite the $\sin (\mathrm{a}+\mathrm{b})$ and $\sin (\mathrm{a}-\mathrm{b})$ formulas they have found. After that they are asked to find the value of $\sin (a+$ b) and $\sin (\mathrm{a}-\mathrm{b})$ if known $\mathrm{a}=30^{\circ}$ and $\mathrm{b}=30^{\circ}$. So that students can prove for themselves whether the formula they have found is true or falsely seen from the results of the calculation, because for $\sin (\mathrm{a}+\mathrm{b})$ worth degan $\sin 60^{\circ}$ ie $\frac{1}{2} \sqrt{3}$, while for $\sin (\mathrm{a}-\mathrm{b})$ worth of $\sin 0^{\circ}$ is 0 . If the answer which they give is true then they can continue the activity to the implementation stage, whereas if they can not find the right answer, they should check their work again in the Data Addition stage and can discuss with friends or teachers until they get the correct answer.

6

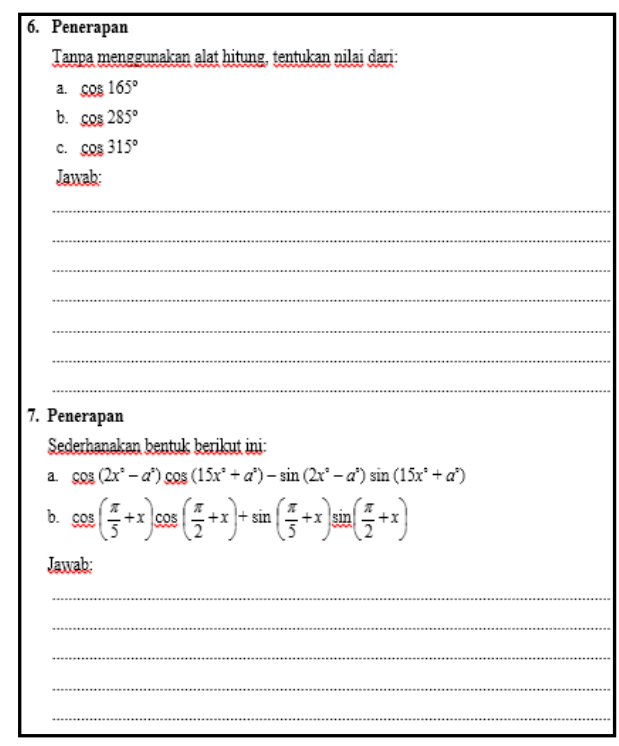


In the example above, students are given problems to enrich students' experiences in using the formulas they have found.

As for result of learning device development in this research is as follows:

a. Validation of The Devices

The assessment of student worksheet consists of two aspects, namely in terms of material and media. In terms of material includes three aspects namely aspects of Guided Discovery, aspects of Material Quality of the student worksheet, and aspects of Educational Conditions. While in terms of media cover aspects of the Terms of Construction, Technical Requirements, Aspects of Evaluation, and Aspects of the Implementation. Here are the validation results of all three validators and their analysis.

Table 3. Validation results from the student worksheet in terms of content

\begin{tabular}{llc}
\hline No. & Aspects & Average score \\
\hline 1. & Guided Discovery & 3,61 \\
2. & Student Worksheet Content Quality & 3,38 \\
3. & Didactic Condition & 3,53 \\
Average Score per Content & 3,51 \\
\hline
\end{tabular}

Table 4. Validation results from student worksheet in terms of media

\begin{tabular}{llc}
\hline No. & Aspects & Average score \\
\hline 1. & Construction Condition & 3,43 \\
2. & Technical Condition & 3,62 \\
3. & Evaluation Aspect & 3,33 \\
4. & Implementation Aspect & 3,33 \\
Average Score in terms of media & 3,42 \\
\hline
\end{tabular}

Table 5. Validation result of the test

\begin{tabular}{|c|c|c|c|}
\hline Item & Name of Validator & Feasibility & Conclusion \\
\hline \multirow{3}{*}{$\begin{array}{l}\text { Problem } \\
1\end{array}$} & Validator 1 & $\mathrm{Fu}$ & \multirow{3}{*}{ Fui } \\
\hline & Validator 2 & Fui & \\
\hline & Validator 3 & Fui & \\
\hline \multirow{3}{*}{$\begin{array}{l}\text { Problem } \\
2\end{array}$} & Validator 1 & $\mathrm{Fu}$ & \multirow{3}{*}{$\mathrm{Fu}$} \\
\hline & Validator 2 & $\mathrm{Fu}$ & \\
\hline & Validator 3 & $\mathrm{Fu}$ & \\
\hline \multirow{3}{*}{$\begin{array}{l}\text { Problem } \\
3\end{array}$} & Validator 1 & $\mathrm{Fu}$ & \multirow{3}{*}{$\mathrm{Fu}$} \\
\hline & Validator 2 & $\mathrm{Fu}$ & \\
\hline & Validator 3 & $\mathrm{Fu}$ & \\
\hline \multirow{3}{*}{$\begin{array}{l}\text { Problem } \\
4\end{array}$} & Validator 1 & Fui & \multirow{3}{*}{ Fui } \\
\hline & Validator 2 & $\mathrm{Fu}$ & \\
\hline & Validator 3 & $\mathrm{Fu}$ & \\
\hline
\end{tabular}

Information:

$\mathrm{Fu} \quad:$ Feasible to use

Fui $\quad$ : Feasible to use with improvement

From the tables above, the mathematics instructional devices based on guided discovery in topic of trigonometry for student grade XI science program developed in this study include RPP in which includes student worksheet and test. Based on the results of 
validator assessment, the developed device is valid with details for the lesson plan categorized valid with the value of each aspect above 3. For the student worksheet in terms of material and media terms, both have scores above 3. While for the Test Results of Learning, based on the assessment of experts, the test is categorized valid with minimum criteria obtained is fui or feasible to use with improvement.

In addition, the majority of students have no difficulty in understanding the words contained in the developed student worksheet and test. This is in line with the results obtained in the student response questionnaire about the language comprehension aspects used in the student worksheet and test, where only 3\% of the total students of the experimental class are having difficulty understanding the language used. So the test and student worksheet developed have a good level of legibility.

b. Student Activity

The results of research on student activity during instructional devices developed showed that some aspects of student activity for all lesson plans are not within the ideal criterion of ideal time tolerance limits. Thus, the overall activity of the students during Guided Discovery learning on the categorized trigonometric material is less effective due to several things. In the aspect of listening or paying attention to the teacher's explanation, in addition to having to condition the student during the start of the lesson by explaining the introduction of the lesson, the teacher also has several times to answer or explain in front of the class about students who are confused in the calculations of finding derivative trigonometric formulas.

As for the aspects of reading a student book or student worksheet, the time required in fact is more than 2 minutes which is about 6 to 7 minutes total during the learning process. This is because many students tend to be crowded when asked to read the instructions in the student worksheet first.

For aspects working on student worksheets/writing relevant to teaching-learning process, students tend to be faster than those allocated in the lesson plan in working out the steps to find the formula in the student worksheet. Therefore, the percentage of student time in working on student worksheets below the tolerance interval.

In the questioning aspect of the teacher, the four students who were observed several times asked the teacher about things that they felt were still confusing resulting in a question and answer process that took more time than the specified time interval.

On irrelevant aspects of behavior, this is difficult to avoid because of the influence of the environment of about four observed students who break their concentration. Based on the above conditions, the student activity for some aspects is below or above the tolerance interval which resulted in less effective student activity.

By reason of the ineffectiveness of student activities, the lesson plan was improved and re-validated to the experts. The validation result is that the repaired lesson plan can be categorized as valid because the minimum average rating of the three validators is above 3. In addition, the three validators assume that the lesson plan that has been improved is feasible to produce, and practically that can be applied in theory.

c. Teachers' Ability to Manage The Class

In the implementation of this learning, the ability of teachers to manage learning is observed for 3 times on July 28, 2015, August 1, 2015, and August 4, 2015. Based on the observation of the ability of teachers in managing the class that has been analyzed shows that the score obtained in every aspect observed in managing the class there is no score below 3. This means that the ability of teachers in managing the class was good. 


\section{d. Students' Response}

In the experimental phase of learning, students' response to learning shows a positive response. The results of student response analysis indicate that the majority of students are interested in learning Guided Discovery where the number of percentage of students who choose Pleased on aspects of student responses to the learning component as much as $93.5 \%$, and the category Interested in the question "What do you think if for subsequent learning using Guided Discovery method?" As much as $86.7 \%$.

e. Test

Based on the score obtained from the Test, as many as $76.7 \%$ of students completed, this means that the classical completeness is achieved. In addition, the results of the validity, reliability, and sensitivity of the test showed that the test developed (1) was categorized valid with the minimum prevalence level achieved was 0.53 or sufficiently categorized, (2) reliably categorized with a moderate reliability level of 0.67 , And (3) categorized as sensitive with the minimum sensitivity index achieved is 0.51 . Then it can be concluded that the test developed can be used.

2. The Effectiveness of The Learning Process Using The Developed Instructional Devices

a. Students Response

In the implementation stage, the percentage of students who choose the Happy category on the student response aspect to the learning component is $92.9 \%$, and the students who choose the category Interested in the question "What do you think if for next learning using Guided Discovery method?" As much as $85.7 \%$.

This means students are more likely to be interested in Guided Discovery based learning. So it can be concluded that the student response to Guided Discovery based learning was positive. This shows that some opinions from the experts such as Brunner on the need for Guided Discovery methods where one of the way to change the motivation of students who originally came from outside into themselves, which is in line with the results of research showing that students are interested in learning trigonometry using the method of Guided Discovery at the next meeting.

b. Teacher's Ability in Managing The Class

Based on the analysis of the ability of the teacher to manage the class, the average value obtained from all criteria is 4.9. This means that learning management is good. The process and the flow of learning was done the same as the process and the flow that was done in the test phase.

\section{c. Student Activities}

From the results of the student activity analysis at each meeting, the results obtained that during trigonometric class, some students can concentrate in finding trigonometric derivative formulas through the student worksheet that has been developed. This can be shown from the analysis that the largest percentage of students are active in working on student worksheets. In addition, some of them actively discussed their findings and were able to explain their findings in front of the class.

However, from several aspects of student activity observation it is found that only one aspect is effective in the discussion (Listening / hearing / answering / responding to questions) with the teacher / friend.

The ineffectiveness of other aspects is due to the precise approximation of time allocation for each activity that is not in accordance with the ideal time tolerance interval. An example is on aspects of "working on student worksheets/writing that are relevant to 
the teaching-learning process". In reality in the classroom, students can work on student worksheets faster than the estimated time allocated in the lesson plan.

Another example is the Reading aspect of the student worksheet. In this case, the 2 minute time to read is too fast for some students, so for the time allocation for the aspect of Reading the student worksheet can be added to 4 - 5 minutes.

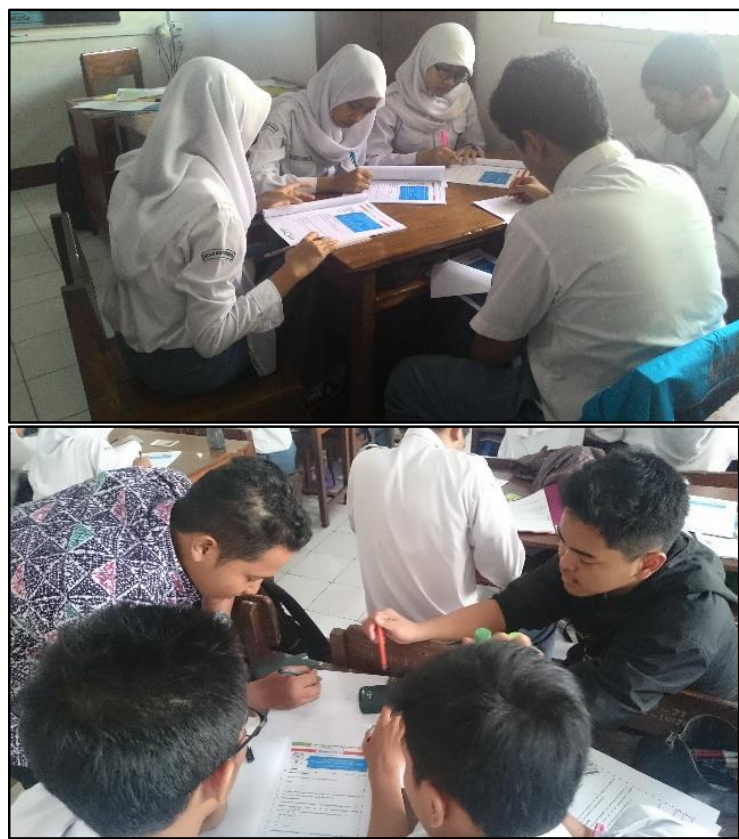

Figure 5. Students focus on working student worksheets in groups and active students discuss with teachers and friends.

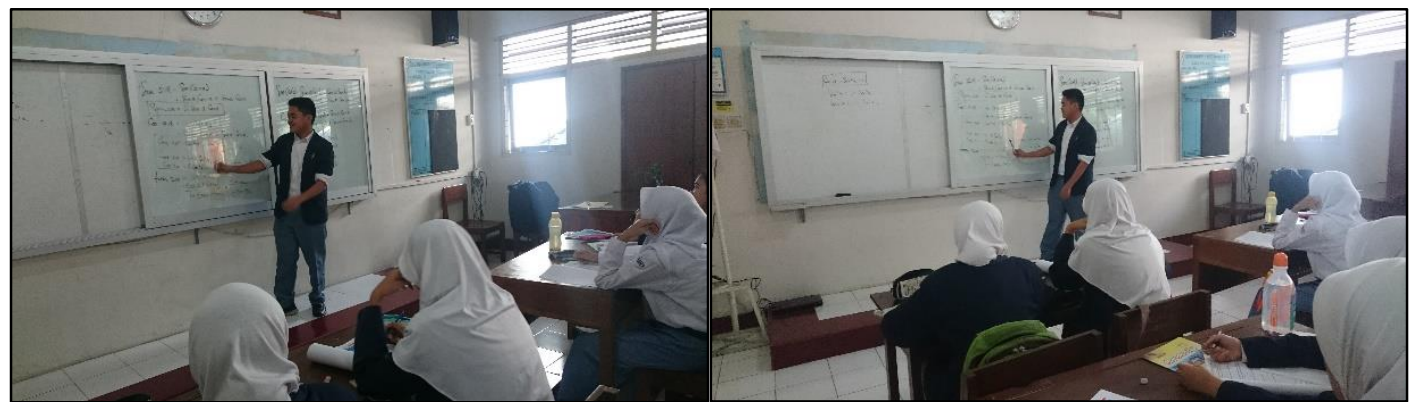

Figure 6. One student advanced to the front of the class to explain the findings

\section{d. Test}

Based on the results of the analysis of student learning outcomes in the learning process based on Guided Discovery on trigonometric materials for students of grade XI science program, students class XI IPA 5 which in this study as an Implementation class get classical completeness of $82.1 \%$ of 28 students. Or in other words only 5 people are not complete. So trigonometric learning based on Guided Discovery can optimize students' academic learning outcomes. This is in accordance with the opinion of Nieveen (1999: 26) that learning is said to be effective if the device reflects the student experience and expected student learning outcomes. 


\section{Conclusion}

Based on data analysis and discussion of research result of learning Guided Discovery on trigonometric material for students of grade XI science program obtained some conclusion as follows:

1. Based on the development design of ADDIE, learning tools produced by Guided Discovery on trigonometric materials for students of class XI science program consisting of lesson plan which includes student worksheet and test.

2. Instructional devices developed do not meet the criteria of proper device because of the ineffectiveness of student activities of the four students observed, but for other aspects such as device validity, practicality, and some aspects of effectiveness such as classical completeness and student response are met. The translation is as follows:

a. Instructional device valid based on validation result analysis.

b. Teacher's ability in managing the class was good.

c. Student's response was positive, as indicated by the percentage of students who chose Happy in the student response aspect to the learning component as much as $93.5 \%$, and the category Interested in the question "What do you think if for next learning using Guided Discovery method?" As much as $86.7 \%$.

d. The test of learning results shows the accomplishment of classical achieved, and has the validity of at least enough, the coefficient of reliability is moderate, and all the test items are sensitive.

3. The Guided Discovery Learning process on trigonometric materials for XI graders science program was less effective due to the aspects of the effectiveness of student activities are not met. But for other aspects have been met with the following description:

a. Classical learning completeness was fulfilled, that is as much as $82,1 \%$.

b. The student's response to learning is positive, as indicated by the percentage of students who chose the Happy category on the student response aspect to the learning component as much as $92.9 \%$, and the students who chose the category Interested in the question "What do you think if for next learning use Guided Discovery method?" As much as $85.7 \%$.

c. Learning process implemented by the teacher is good, which is indicated by the average score of teachers' ability to manage learning is more than 3 .

\section{Bibliography}

Bell. F. H., 1978, "Teaching and Learning Mathematics (In Secondary Schools)", Iowa: Wm. C. Brown Company Publisher

Bruner, Jerome. 2011, "Discovery Learning (Bruner)". Retrieved at April 12 ${ }^{\text {th }}$, 2016, http://www.learning-theories.com/discovery-learning-bruner.html.

Carin, A. A.. 1993. “Teaching Science Through Discovery," New York: Mcmillan Publishing Company.

Cooney, T.J. Davis, \& Henderson, K.B., "Dynamics of Teaching Secondary School Mathematics", Boston: Houghton Mifflin Company

Hammerman E., 2006, "Becoming A Better Science Teacher: 8 Steps to High Quality Instruction and Student Achevement", California: A SAGE Publication Company 
Markaban, 2006, "Model Pembelajaran Matematika Dengan Penemuan Terbimbing". Working Paper. Delivered in modules writing of upgrading packet. Yogyakarta: PPPG Matematika.

Moore, K. D.., 2005, "Effective Instructional Strategies: From Theory to Practice", California: Sage Publication

Nieveen, Nienke. 1999. Prototyping to Reach Product Quality. In Jan Van den Akker, R.M. Branch, K. Gustafson, N. Nieveen \& Tj. Plomp (Eds). Design Approaches and Tools in Education and Training (pp 125 - 135) Kluwer Academic Publishers, Dordrecht, the Nederlands.

Riduwan. 2009. Skala Pengukuran V ariable-V ariabel Penelitian. Bandung: ALFABETA.

Samuel, V. 2014, "Guided Discovery for Language Instruction: A Frameworks for Implementation at all Levels". Retrieved at April 12 ${ }^{\text {th }}, 2016$, http://www.pearsonlongman.com/ae/emac/newsletters Lguideddiscovery.pdf.

Sasmito, E. 2012. "Pengembangan Perangkat Pembelajaran Model Penemuan Terbimbing untuk Materi Rumus-Rumus Trigonometri Di Kelas X SMA Negri I Tuban," Thesis, Surabaya: UNESA.

Susanto, R. H., 2008, “Trigonometri: Membangun Kekuatan Konstruksi Kognitif”, Yogyakarta: CV. Grafika Indah. 